\title{
INTRODUCTION
}

\section{Borderscapes: From Border Landscapes to Border Aesthetics}

\author{
ELENA DELL'AGNESE \\ ANNE-LAURE AMILHAT SZARY
}

\section{QUERY SHEET}

This page lists questions we have about your paper. The numbers displayed at left can be found in the text of the paper for reference. In addition, please review your paper as a whole for correctness.

There are no Editor Queries for this paper.

\section{TABLE OF CONTENTS LISTING}

The table of contents for the journal will list your paper exactly as it appears below: INTRODUCTION

Borderscapes: From Border Landscapes to Border Aesthetics Elena dell'Agnese and Anne-Laure Amilhat Szary 


\title{
INTRODUCTION
}

\section{Borderscapes: From Border Landscapes to Border Aesthetics}

\author{
ELENA DELL'AGNESE \\ Sociology and Social Research, University of Milano-Bicocca, Italy \\ ANNE-LAURE AMILHAT SZARY \\ Institut de Géographie Alpine, Université Joseph Fourier, Grenoble, France
}

Can cultural production be more than a side-issue in border studies? The following set of papers clearly makes a move towards a new way of answering the question positively. It is important to take cultures of all kinds-whether conforming with "popular," "classic," or "avant-garde" categories-into account in order to understand bordering dynamics, as their comprehension can usefully be utilized to enlarge the conceptual framework from which, and with which, we consider the border. This assertion is primarily based on the multiplication of artistic artifacts in borderlands, on the border itself, or about the bordering processes, the diversity of which is acknowledged in this special issue of Geopolitics. It also rests on the fact that cultural production and borders have developed a more-than-representational relationship ${ }^{1}$ that appears to reveal a lot of the political mechanisms at work in the spaces concerned by borders and border-crossings.

Unheard of till the turn of the century, the word "borderscape" is now trendy. It is presumed to have been coined by the performance artists Guillermo Gómez-Peña and Roberto Sifuentes, ${ }^{2}$ who used it for the first time in the title of a performance in 1999: Borderscape 2000: Kitsch, Violence, and Shamanism at the End of the Century. ${ }^{3}$ Then, after a short period of disuse, the term resurfaced, or was reinvented. In 2003 it was used by Arjan Harbers in the essay "Borderscapes, the Influence of National Borders on European Spatial Planning," included in a book entitled Euroscapes. ${ }^{4}$ In

Address correspondence to Elena dell'Agnese, Sociology and Social Research, University of Milano-Bicocca, Via Bicocca degli Arcimboldi, 8, 20126 Milano, Italy. E-mail: elena.dellagnese@unimib.it 
2004, it appeared in a book chapter written by Gabi Dolff-Bonekämper and Marieke Kuipers. ${ }^{5}$ In 2005, it was used by Elena dell'Agnese in the title of a paper presented at the AAG pre-conference of the Political Geography Specialty Group of the Association of American Geographers, in Boulder, Colorado. ${ }^{6}$ A few months later it was used by Anke Strüver in the title of her book, Stories of the "Boring Border": The Dutch-German Borderscape in People's Minds. ${ }^{7}$

Since then, the word has been used and popularized through many channels. Other publications and initiatives include the book published in 2007, edited by Prem Kumar Rajaram and Carl Grundy-Warr; ${ }^{8}$ a series of Euroscapes conferences, organized by Elena dell'Agnese with the Commission on Political Geography of the International Geographical Union (IGU-CPG), respectively in Trento (2006), ${ }^{9}$ Trapani (2009) ${ }^{10}$ and Trieste $(2012)^{11}$; various research initiatives, ranging from small research projects such as the one submitted to the Institut universitaire de France by AnneLaure Amilhat Szary in 2009 to very big EU research programs, such as Euroborderscapes, an EU FP7 research project, on which 19 universities throughout Europe collaborated ${ }^{12}$; and the consortium BORDERscape, an international curriculum development project that involves short-term transatlantic student and faculty mobility between the Humboldt-Universität zu Berlin, Oregon State University, the University of Warsaw and the University of Washington. Nowadays, speaking about borderscapes is almost a fashion, even if there is no unequivocal definition of the term. Quite the contrary, the word, a portmanteau that combines aspects of "landscape" and "border", brings with it all the unresolved ambiguities of the two separate notions and multiplies them. And it may even generate additional misunderstandings, given the fact that the suffix "-scape" has been adopted and transformed by the anthropologist Arjun Appadurai into something far from its original meaning, referring to "a wide view of a place, often one represented in a picture", which has since developed into something very fashionable in itself. ${ }^{13}$

For these reasons, at least three different meanings coexist since the word "borderscape" first appeared on the academic and artistic scenes. In chronological order, we distinguish first the meaning implied by GómezPeña's theatre performance. According to Josh Kun, ${ }^{14}$ this should be considered in relation with Appadurai's work, since the use of the suffix "-scape" may be connected with the latter's analysis of global capitalism, its disjunctures and flows. Thus, the scapes in question are more like circuits of images and ideas than "landscapes" in the proper sense of the word. Although not necessarily used in connection with Gómez-Peña's work, this idea of borderscape, as we are given to understand by Chiara Brambilla's paper in this special issue, has been very successful both among geographers and beyond the discipline. As Henk van Houtum, Martin van der Velde, and Joren Jacobs observed: 
"(w)e are inspired, in this respect, by Appadurai's notion of scapes. In his book Modernity at Large Arjun Appadurai (1996) suggests to use the word 'scape' as building block of the new transnational imagination. [. . .] Appadurai's scapes can be approached in different ways. The border area is shaped; it is a constructed reality. Thus, it can also be reshaped and redesigned transnationally". ${ }^{15}$

So, a borderscape is an area, shaped and reshaped by transnational flows, 80 that goes beyond the modernist idea of clear-cut national territories.

This is apparently very far from the notion of the "borderscape" provided by Harbers. In Harbers' approach, a borderscape is understood as a physical landscape marked by the presence of a boundary. From this standpoint, Harbers focuses on the role of the nation-state in shaping and reshaping the area surrounding the boundary. As specified by Harbers:

"(w)e shall describe the distortions borders bring to the built environment or nature as 'border solidifications', or borderscapes". ${ }^{16}$

In this definition, the borderscape is the material output of the difference in sovereignty marked by the international boundary. If the idea of borderscape is recent, the approach is firmly in line with the disciplinary tradition of Political Geography. Indeed, in 1935 Derwent Whittlesey ${ }^{17}$ published a paper about "The impress of effective central authority upon the landscape," where the consequences of boundaries "upon the landscape" were largely taken into account. But Whittlesey was not the first geographer who tried to understand how the State could affect the landscape. In 1932, a German author called Hugo Hassinger had already published an article in the Zeitschrift fur Geopolitik on "Der Staat als Landschaftsgestalter," ${ }^{8}$ which translates as the State as a creator of landscape. And again, boundaries and their role in reorganizing human activities and spaces were largely taken into account. ${ }^{19}$

A little less centred on the direct intervention of the State, but, generally speaking, similar to Harbers' approach, is Gabi Dolff-Bonekämper and Marieke Kuipers' notion of "borderscape" 20 in a Council of Europe report. They also treat the term "borderscape" simply as a "crasis" of the words "border" and "landscape" (as is revealed by the French edition of the report, where the word "borderscape" is simply translated as "paysage frontalier" or border landscape). ${ }^{21}$ They focus on the role of boundaries in transforming the territorial configuration of adjacent lands, maintaining an approach quite similar to the one developed by Julian Minghi and Dennis Rumley in their famous book The Geography of Border Landscapes. ${ }^{22}$ While Harbers uses the notion of borderscape to describe the distortions imposed by the limits of sovereignty on the physical management of the land, Dolff-Bonekämper and Kuipers use it to describe a "borderland", that is to say a portion of land surface influenced by the presence of an international boundary. ${ }^{23}$ Both 
in Harbers' and Dolff-Bonekämper and Kuipers' interpretations, the idea of landscape corresponds more or less to the idea of a (border) "region."

This understanding of "landscape" as a given and "objective" set of forms corresponds to the "classic" approach to the concept popularized by Carl Sauer in Anglo-American cultural geography in the first half of the twentieth century. Still popular in many other disciplines, this idea of landscape as an objective set of forms has largely been replaced in cultural geography by a different approach to the landscape. The new concept stresses that the landscape is something perceived, but even more importantly something that is perceived differently by each individual. In other words, it is a "signifying system" in which meanings are made and remade by the perceiver-observer. In this perspective:

"the landscape idea represents a way of seeing - a way in which some have represented to themselves and to others the world about them and their relationships with it, and through which they have commented on social relations. Landscape is a way of seeing that has its own history, but a history that can only be understood as part of a wider history of economy and society; [. . .] that has its own techniques of expression, but techniques which it shares with other areas of cultural practice". ${ }^{24}$

Landscape, as a representation-perception, has not only a visual dimension. On the contrary, the importance of writing and mapping in the making of a landscape and its many meanings must be highlighted. "The representations of landscape", as Trevor Barnes and James Duncan write in the preface of their seminal volume Writing Worlds. Discourse, Texts, and Metaphors in the Representation of Landscape ${ }^{25}$

"are not mimetic, but rather a product of the nature of the discourse in which they are written ...".

Landscape, from this perspective, can be represented in different forms, such as maps, literary texts, and painting. Each of these representations must be accepted as a "signifying practice." Again, a signifying practice is not read and interpreted passively, but is rewritten and reinterpreted by the reader-spectator. Each of these texts is constitutive of larger structures termed "discourses," practices of signification, which provide a framework for understanding the world.

This approach to the idea of landscape is shared by Anke Strüver who, in her book, focuses on the representation of the border offered by popular culture. In her opinion, a borderscape is just a way of representing/ perceiving the area around the border:

"A borderscape [. . .] brings together the two dimensions of representations [...] It relies on narratives, images and imaginations as imagined 
realities of the border which are constitutive of its meanings and effects, including the practices with relation to the border [. . .] And similar to the term landscape, as both noun and verb, borderscape also and always refers to borderscaping - of shaping the border not on the ground, but in people's minds. The borderscape - shaped though representations of all kinds - implies borderscaping as practices through which the imagined border is established and experienced as real."

Border aesthetics are rooted in the fact that contemporary art can no longer be considered merely an illustrative process of a social reality. All the papers of this special issue attest to the performative nature of borders and henceforth question their ambiguity. From music to caricature, through literature and visual arts, all of the cultural objects on which the authors focus make the border; they scape its material and imaginary universes even when their explicit purpose is to resist the dominating border regime. Therefore the aesthetic analysis of the border allows us to grasp both de- and re-bordering processes, allowing us to move away from all kinds of binaries that usually help to frame the understanding of limits of all kinds. Paradoxically, aesthetic analysis helps to reframe border studies within the liminality paradigm that has been developed by critical cultural studies. ${ }^{26}$

Social scientists have not invented "border art" as an analytical category: the very name comes from the US-Mexico confines where a collective of Chicano-inspired artists, the BAW-TAF (Border Art Workshop - Taller de Arte Fronterizo), was created in 1984, notably by the performance artist Guillermo Gómez-Peña already mentioned in this text. This category may not account for the diversity of cultural expressions that the border condition arouses. Nevertheless, it allows us to "go beyond an analysis that considers the border as the context of the imaginary creation, to try and understand why the boundary allows the opening up of the creative field, contributing to an aesthetic renewal." 27 This is what the first articles in this collection try to establish. By proposing reliance on a new concept, that of "borderscape," one that embraces the sensible dimensions of analysis, Chiara Brambilla shows the way to "connect border experiences with border representations by rethinking borders through the relationship between politics and aesthetics." Her use of the notion is confirmed by the strong proposal contained in Johan Schimanski's literary approach which begins by coming back to philosophical definitions, distinguishing between the three aspects on which the usual definition of aesthetics is grounded: "perception, beauty and art." This useful distinction helps us understand why an aesthetical relation to borders does not rely on a subjective appreciation of their beauty. The "postmodernist sublime" is another way of expressing how the mundane imaginary of borderlands is liable to inspire any kind of artistic production. In the case of Schimanski's article, novels by John Fowles and Kjartan Fløgstad explore both the literary and metaphorical universes 
of Scandinavian borderlands. The performative power of aesthetic objects is very well expressed by the notion of "poetics" developed by Valerià Paül and Juan-Manuel Trillo-Santamaría, referring both to the lyrical dimension of the literary heritage of Spanish and Portugal borderlands and to its capacity to initiate regional re-appropriations that escape traditional territorial processes: In other words, its "poiesis" (creative power). To these authors as well as to all the contributors to the special issue, border aesthetics is another way of expressing the relational dimension of socio-spatial interfaces and of questioning their political component.

The following two articles address the political impact of cultural production at the border. The spatial turn of visual and contemporary arts implies that the creators of artistic objects are making explicit use of the place in which they locate their work. Based on the situationist tradition that denounces the political spectacle by public intervention and on the claiming of public space through the power of the aesthetical relation, many cultural creations can be analyzed through the lenses of counter-politics and resistance to imperial geopolitics. Following Rancière's proposal to look at the capacity of aesthetics to recreate the conditions for a "dissensus" that market democracy has evacuated ${ }^{28}$ artists' work can be interpreted through the quest for symbolic opposition. In their analysis of the productions of European contemporary visual artists, such as Bajevic, Hatoum, Salcedo, Rosver and Meredith-Vula, Cristina Giudice and Chiara Giubilaro look at the ways "artists are able to challenge dominant representations and hegemonic discourses, making the border an active site of resistance and struggle". In turn, Kenneth Madsen skillfully builds on this debate from the viewpoint of a more popular kind of border art, that of inscriptions on the border barrier that walls off Mexico from the United States. The diversity of the artifacts that he meets in the field allows him to describe "graffiti art on border barriers [as] a liminal category between casually subversive graffiti thrown up quickly and anonymously and public art or other commissioned works which are planned out, credited to known artists, and approved by public authorities and property owners." He thus brings back into the debate the question of the ambiguous nature of cultural production in and around border spaces where it both contributes to de-essentializing the border landscape and reframing imaginaries that cope with the growing securitization of international limits.

Another set of articles focuses on an essential tool of the bordermaking process, the map. It has been often recalled that the invention of the Westphalian border was concomitant with the technical tool that allowed its representation on paper, and that both constitute aspects of the governmental apparatus that has served to design the territorial nation-state. Since the second half of the twentieth century, many artists have gone back to this codified representation of the world to both deconstruct it and use it as a source of counter-power, thus refocusing on the initial and historic aesthetic 
component of the map that modernity had tried to erase. ${ }^{29}$ In this context, André Reyes Novaes takes the opportunity of a journalistic competition about the border between Columbia and Venezuela, addressed to both the readership of the newspaper in question and a number of professional artists, to query the contemporary reframing of the art-science relationship taking map drawing as its subject. The conclusion that "so many artists recreated the boundaries on a map that intended to erase them" induces him to reintroduce the violent dimension of borders that aesthetics also entails. In a strange and original manner, this text comfortably fits with Edoardo Boria's study of counter-mapping as a historical device used by all of the famous authors of geopolitics, the "Reclus, Mackinder and Others", as he calls them. His thorough study of some of the most imaginative illustrations of our geopolitical classics allows him to scan, using the same analytical framework, ideologically completely opposed texts and to draw attention to the commonalities of their use of imaginaries.

Finally, a last set of articles brings to the fore two other media music and film - to broaden the panorama of aesthetic borderscaping. Little research, at least from a political geography perspective, has been undertaken on what Josh Kun has defined as the "aural border," or the audioscape: this idea is approached in terms both of border music (the music produced in the border area), and of "border crossing music" (the music about the experience of crossing the border). Elena dell'Agnese questions the notion of cultural region or area by coming back to the US-Mexico divide, which she presents as the paramount divide in many ways: notably, how it is not only the cradle of very intense local musical traditions but also appealing in global contemporary popular music, as a kind of universal reference to distancing and hybrization processes. Last but not least, Michael J. Shapiro takes inspiration from two TV series, The Wire (five seasons, 2002-2008) and Deadwood (three seasons, 2004-2006), to explore the evolution of the notion of frontier within our imaginaries. Stressing it as a space of possibility, open to all kind of both legal and illegal confrontations and negotiations, he defines the frontier as the place of multiple borders that can coalesce for story building.

The articles collected in this special issue bridge political and cultural geography, and engage a dialogue with other social sciences. They build upon a more sophisticated interpretation of the notion of landscape ("a thing that is also the representation of the thing") ${ }^{30}$ and, as a consequence, of the idea of borderscape. The issue starts from acknowledging that the landscape as a representation is far from being "objective": it does not have a preexisting meaning, which can be understood in the same way by every kind of audience but, on the contrary, is the result of a sum of interpretations and re-interpretations. Historically and culturally influenced, the borderscape is the product of an intricate web of intertextualities, and it is full of tropes. In turn, a border aesthetics perspective allows us to reframe the very notion 
of representation by questioning the quality of the relational links that the notion of place mediatizes.

Building on Michael J. Shapiro's engagement with "border stories," we may suggest that border aesthetics is vital to border studies because it enables us to reframe the narrative setting of our conceptual work. This opens the ground for questioning the positionality of the investigator, because we are all, as the poet Gloria Anzaldúa suggested, deeply linked with these places where we have to confront the Other as much as ourselves. Let us recall those lines from her poem entitled: To live in the Borderlands means you:

"[....]

In the Borderlands

you are the battleground [. . .]

you are at home, a stranger [. . .]

[...]

you are wounded, lost in action [. . .]

To survive in the Borderlands

you must live sin fronteras

be a crossroads". 31

\section{NOTES}

1. N. Thrift, Non-Representational Theory. Space, Politics, Affect (New York, London: Routledge, 2008); M. Dear, J. Ketchum, S. Luria and D. Richardson (eds.), GeoHumanities. Art, History, Text at the Edge of Place (London/New York: Routledge 2011)

2. There is also an article, by R. Chavez Chavez, ' $\mathrm{W}^{\circledR} \mathrm{i}(\mathrm{t} / \mathrm{d})$ ing on the border: reading our borderscape', Theory and Research in Social Education, 27/2 (Spring 1999), pp. 1-24. Here, no explanation of the meaning of the term is offered.

3. See J.D. Kun, 'The Aural border', Theatre Journal, 52/1 (March 2000), pp. 1-21, for a discussion of the script, and also J.D. Kun, 'Multiculturalism Without People of Color: An Interview With Guillermo Gómez-Peña', Aztlán: A Journal of Chicano Studies, 24/1 (Spring 1999), pp. 187-199; and J.D. Kun, 'Audioscape 2000: The Pocha Nostra and the performance of Sound', in R. Uno and L. Mae San Pablo Burns (eds.), The Colour of Theatre: Race, Ethnicity and Contemporary Performance (New York: Continuum 2001), pp. 375-381.

4. See A. Harbers, 'Borderscapes, The Influence of National Borders on European Spatial Planning', in R. Brousi, P. Jannink, W. Veldhuis and I. Nio (eds.), Euroscapes (Amsterdam: Must Publishers/Architectura et Amicitia, 2003).

5. G. Dolff-Bonekämper and M. Kuipers, 'Boundaries in the Landscape and in the City', in G. Dolff-Bonekämpe (ed.), Dividing Lines, Connecting Lines - Europe's Cross-Border Heritage (Strasbourg: Council of Europe, 2004), pp. 53-72.

6. E. dell'Agnese, Bollywood's Borderscapes, Paper presented at AAG Pre-Conference at the University of Colorado at Boulder, CO., April 3-5, 2005 http://www.colorado.edu/ibs/aagpreconference/ papers/abstracts.html.

7. A. Strüver, Stories of the 'Boring Border': The Dutch-German Borderscape in People's Minds, Forum Politische Geographie, Bd. 2 (Münster: LIT-Verlag, 2005). The book is based on a PhD thesis with the same title defended in 2004 at Radboud University Nijmegen.

8. P. Kumar Rajaram and C. Grundy-Warr, Borderscapes: Hidden Geographies and Politics at Territory's Edge (Minneapolis: University of Minnesota Press, 2007).

9. http://web.unitn.it/archive/events/borderscapes/index.htm. 
10. With Giulia de Spuches, Borderscapes II. Another Brick in the Wall

11. With Sergio Zilli, www2.units.it/borderscapes3.

12. http://www.euborderscapes.eu/, and V. Kolossov, Euroborderscapes: State of the Debate. Report 1, European Commission (2012).

13. "Healthscape, Medscape -this industry always works this way. For a while it was 'object this' and 'object that', then 'net' and even 'net object.' These things aren't terribly sophisticated; it's like fashions in children's names. And a good name can add 200\% to your valuation" - Esther Dyson, publisher of Release 1.0, a technology newsletter, on the recent spate of new companies named with the suffix scape", New York, April 1966, p. 15. Quoted by D.L. Gold, in 'Nouns and Verbs Ending in - scape', Revista Alicantina de Estudios Ingleses, 15 (2002), pp. 72-94.

14. J.D. Kun, 2000 (see note 3).

15. H. van Houtum, M. van der Velde and J. Jacobs, Demographic and Economic Decline as Symptoms of Peripherality: Plea for the Planning and Design of a Borderscape, Nijmegen Centre of Border Research, available at https://www.academia.edu/2864686/Demographic_and_economic_decline_ as_symptoms_of_peripherality_Plea_for_the_planning_and_design_of_a_Borderscape, 2010. See also J. Jacobs, 'Borderscapes als ontwerp', Agora 4 (2012), pp. 9-13.

16. See Harbers (note 4).

17. D. Whittlesey, 'The Impress of Effective Central Authority upon the Landscape', Annals of the Association of American Geographers, XXV/2 (June 1935), pp. 85-97.

18. H. Hassinger, 'Der Staat als Landschaftsgestalter', Zeitschrift fur Geopolitik, IX (1932), pp. 117-22, $182-87$.

19. J.R. Victor Prescott, who, in his celebrated Political Frontiers and Boundaries (London: Allen \& Unwin 1987), outlined four areas of concern in the relation between landscape and boundaries: 1) the political boundary as an element of the cultural landscape; 2) the effect of the boundary upon the landscape and on economic activities; 3) any impact the boundary might have on the attitudes of border inhabitants; 4) the effect of the boundary upon State policy. Apart from these classic works in the field of political geography, the influence of boundaries on landscape was taken into account also on the side of landscape studies. For instance, the editor of the journal Landscape, John Brinckerhoff Jackson distinguishes in his Discovering the Vernacular Landscape (New Haven, London: Yale University Press 1984) between "vernacular landscape", that is the landscape resulting from everyday life, and "political landscape", that is the landscape resulting from the intervention of the State ("the political landscape is deliberately created in order to make it possible for men to live in a just society, the inhabited landscape merely evolves in the course of our trying to live on harmonious terms with the natural world ..."). Specifically, in the essay 'A Pair of Ideal Landscapes', he identifies boundaries, together with roads and monuments, as the main elements of the political landscape.

20. G. Dolff-Bonekämper and Marieke Kuipers, 'Des frontières dans le paysage et dans la ville', in G. Dolff-Bonekämper (ed.), Patrimoine européen des frontières - Points de rupture, espaces partagés (Strasbourg: Editions du Conseil de l'Europe 2004), pp. 53-72, see note 5.

21. Ibid.

22. J. Minghi and E. Rumley (eds.), The Geography of Border Landscapes (London, New York: Routledge 1991). The book consists of a collection of papers presented at the final meeting of the Study Group on the World Political Map, held at the 26th International Geographical Union Congress in Perth (1988). The Perth meeting was what we would today call a pre-conference, held before the main IGU Congress in Sydney. At the time, the Chair of the Commission was David Knight, who wrote in his preface: "This volume is about border landscapes, with emphasis on the varying impact that political decision-making and ideological differences can have on the environment at border locations".

23. Again, this approach finds its origin in the history of political geography. See S. B. Jones, "The Cordilleran Section of the Canada-United States Borderland", The Geographical Journal, 89, 5 (1937), pp. 439-50.

24. D. Cosgrove, Social Formation and Symbolic Landscape (London: Croom Helm, 1984).

25. T. Barnes and J. Duncan (eds.), Writing Worlds. Discourse, Texts, and Metaphors in the Representation of Landscape (London, New York: Routledge, 1992).

26. H.K. Bhaba, The Location of Culture (New York: Routledge, 2004 [1994]); Mieke Bal, "Introduction", in M. Bal and B. Gonzales (eds.), The Practice of Cultural Analysis: Exposing Interdisciplinary Interpretation (Stanford [CA]: Stanford UP, 1999), pp. 1-14.

27. A.-L. Amilhat Szary, 'Border Art and the Politics of Art Display', Journal of Borderlands Studies, vol. 27 (2) (2012), pp. 213-28. 
28. J. Rancière, Dissensus. On Politics and Aesthetics (New York, London: Continuum, 2010).

29. D. Cosgrove, Mappings (London: Reaktion Books, 1999); K. Harmon, C. Clemans, Gayle, The Map as Art. Contemporary Artists Explore Cartography (New York: Princeton Architectural Press, 2009).

30. F. Farinelli, "L'arguzia del paesaggio", Casabella, 575-576 (1991), pp. 10-12. On Farinelli's ideas, see C. Minca, 'Humboldt's Compromise, or the Forgotten Geographies of Landscape, Prog. Hum. Geog., 31 (2) (April 2007), pp. 179-193.

31. G. Anzaldua, Borderlands/La Frontera: The New Mestiza (25th anniversary - 4th edition) (San Francisco: Aunt Lute Books, 2012 [1987]). 